\title{
Challenges and Prospect to Islamic Accoutants Take on Industrial Revolution 4.0
}

\author{
Agus Arwani \\ Departement Sharia Accounting, Business, and Islamic Economics Faculty, IAIN Pekalongan \\ Email: agus.arwani@iainpekalongan.ac.id
}

\begin{abstract}
The purpose of this study is to provide an overview of the challenges and expectations of Islamic accountants in the industrial revolution era 4.0. This study uses a literary approach, by examining several references relating to the industrial revolution 4.0 relating to Islamic accountants. Theories in research use theories related to the industrial revolution 4.0 and related theories related to collaborative Islamic accounting including Popkoya et all theory IR and Iwan Triyuwono's theory SA. The results of this paper that the Era of the industrial revolution 4 which offers convenience and speed makes people turn into super-fast. Technology is used and developed to accelerate the achievement of every goal set by humans. In the end, the material and psychological needs become inevitable to be forgotten, it will only increase. Professional accountants and Islamic accountants need a pattern of self-management of the basic functions of Islamic accountants and accountants which certainly increases the efficiency and effectiveness of work and the results are immediately known (real-time). The findings of this study include the challenges of Islamic accounting in the face of the industrial revolution including the provision of information that is financial and non-financial IT-based, accountability of financial statements in accordance with SAK Sharia is the main basis for policy makers, Sharia accountants must understand the development of IT-based economics and be able to harmonize conflicts of interest by following the development of information technology. The expectation of Islamic accountants in facing the industrial revolution can be accepted and has the knowledge and skills of IT-based SAK Sharia and can apply digital-based technology, Islamic Accountants always want to innovate in technology development and Islamic accountants are always adaptive in economic and technological development and always want to learn throughout time.
\end{abstract}

Keywords: Challenges, Prospect, Islamic Accountants, IR 4.0

\begin{abstract}
Abstrak
Tujuan dari penelitian ini adalah untuk memberikan gambaran tentang tantangan dan harapan akuntan Islam di era revolusi industri 4.0. Penelitian ini menggunakan pendekatan sastra, dengan memeriksa beberapa referensi yang berkaitan dengan revolusi industri 4.0 yang berkaitan dengan akuntan Islam. Teori dalam penelitian menggunakan teori yang berkaitan dengan revolusi industri 4.0 dan teori terkait yang berkaitan dengan akuntansi Islam kolaboratif termasuk Popkoya et all teori revolusi industri dan Iwan Triyuwono's teori akuntansi syariah. Hasil tulisan ini bahwa Era revolusi
\end{abstract}




\section{JURNAL AKUNTANSI INDONESIA}

industri 4 yang menawarkan kenyamanan dan kecepatan membuat orang berubah menjadi super cepat. Teknologi digunakan dan dikembangkan untuk mempercepat pencapaian setiap tujuan yang ditetapkan oleh manusia. Pada akhirnya, kebutuhan materi dan psikologis menjadi tak terhindarkan untuk dilupakan, itu hanya akan meningkat. Akuntan profesional dan akuntan Islami membutuhkan pola manajemen diri dari fungsi dasar akuntan dan akuntan Islami yang tentunya meningkatkan efisiensi dan efektivitas kerja dan hasilnya segera diketahui (real-time). Temuan penelitian ini meliputi tantangan akuntansi Islam dalam menghadapi revolusi industri termasuk penyediaan informasi yang berbasis TI finansial dan non-keuangan, akuntabilitas laporan keuangan sesuai dengan SAK Syariah merupakan dasar utama bagi pembuat kebijakan, Akuntan Syariah harus memahami perkembangan ekonomi berbasis IT dan dapat menyelaraskan konflik kepentingan dengan mengikuti perkembangan teknologi informasi. Harapan para akuntan Islam dalam menghadapi revolusi industri dapat diterima dan memiliki pengetahuan dan keterampilan SAK Syariah berbasis IT dan dapat menerapkan teknologi berbasis digital, Akuntan Islami selalu ingin berinovasi dalam pengembangan teknologi dan akuntan Islam selalu adaptif dalam ekonomi dan perkembangan teknologi dan selalu ingin belajar sepanjang waktu.

Kata Kunci: Tantangan, Harapan, Akuntan Syariah, Revolusi Industri 4.0

\section{INTRODUCTION}

Prof. Mahfud Sholihin, M.Acc., PhD as the key note speaker presented the title of the Industrial Revolution 4.0 which originally began in 2011 in Germany, where the industrial revolution itself according to Prof. Mahfud Sholihin, M.Acc., PhD is characterized by disruptive technology, big data, and artificial technology. In this material explained that the Industrial Revolution 4.0 is an Industrial Revolution marked by the emergence of supercomputers, smart robots, driverless vehicles, cloud computing, big data systems, genetic engineering and neurotechnology developments that enable humans to better optimize brain function (The Fourth Industrial Revolution by Klaus Schwab, Founder and Executive Chairman of the World Economic Forum). But the Industrial Revolution itself has several threats including that globally the digitalization era will eliminate around 1-1.5 billion jobs throughout 2015-2025, due to the replacement of human positions with automatic machines (Gerd Leonhard, Futurist) and it is estimated that in the future $65 \%$ of elementary school students in the world will work in jobs that have never existed today (US Department of Labor report). Besides having threats, the industrial revolution also has opportunities such as the digitalisation era which has the potential to increase the number of workers to 2.1 million new jobs by 2025, and there is the potential to reduce carbon emissions of around 26 
billion metric tons from three industries: electronics (15.8 billion), logistics (9.9 billion), and automotive (540 billion) from 2015-2025 (World Economic Forum). Meanwhile, Prof. Dr. Hadri Kusuma, who is one of the key note speakers, brought the title "Indonesian Revolution 4 and Accounting Professions" explained that the change was a necessity. Utilizing or becoming a victim is a choice and technology is just a tool like the term a man behind the gun, that the most important thing is who uses the tool. (https://fecon.uii.ac.id/blog/2018/12/09/tantangan-implementasi-keuangan/ )

The world change affects quite large, the impact of the effect of the presence of the development of information technology. This progress by social science experts is called the era of disruption, an era in which all sectors felt the impact, both in the fields of economics, accounting, politics, and education which also felt the impact of information technology transformation. (Harto, K. 2018 )

The development of science and information technology is now running very rapidly. Research in various fields is encouraged throughout the world to create sustainable benefits for the life of living things. As a consequence, various industries must prepare themselves and adapt to the development of information technology, if they do not want to be left behind and lose money. (Purwandini, 2017)

The development of information technology is welcoming the era of sophisticated information technology known as the industrial era 4.0. In this era, technology is projected to dominate all aspects of human life, including the industrial world. Industry 4.0 is a technological revolution concept based on continuous communication via the internet that allows interaction and exchange of information, not only between humans and humans, and humans and machines but also between the machines themselves (Cooper \& James, 2009).

The four main components in Industry 4.0 are Cyber-physical systems (connections between the real world and virtual world), the Internet of Things (loT), the Internet of Services (IoS) and Smart-factories (Roblek, Mesko \& Krapez, 2016). Internet of Things (loT) is a structure where objects and people are given an exclusive identity and the ability to move data in a network without involving human relationships with humans directly, such as the relationship of data sources to the destination (directly, without human assistance) or human interaction with computers (Burange \& Misalkar, 2015). Internet of Things (loT) is a very promising scientific development to optimize life based on smart sensors and smart equipment that works together through the internet network (Keoh, Kumar \& Tschofenig, 2014). Whereas Smart-Factory is a concept where the manufacturing system will be 


\section{JURNAL AKUNTANSI INDONESIA}

equipped with sensors, actors and autonomous systems. Machines have their optimization capabilities and can "make decisions" autonomously.

In industry 4.0 what happens is the automation and digitalization of all aspects of the industry to produce products that satisfy the needs of consumers. Human intervention or manual activity will be reduced by the presence of advanced technology that replaces it. It also includes managing customer data directly obtained from customers that are analyzed and stored in the cloud, as well as the unlimited exchange of information between people and objects through wireless communication networks (Roblek, Mesko \& Krapez, 2016). Accounting and sharia-based accounting must also be prepared to face that era. Islamic accounting appears to be very strategic, and booming in decades will however have to follow the developments in information technology. Ranging from banking, business, products, insurance, self-service, even to the realm of educational institutions participate in using the Islamic label. Certainly no exception to the accounting sector. (Arwani, 2017)

Based on the concept of modern accounting, accounting is neutral, free of value and free of any interest (value free). Likewise, what is touted in the education process with an accounting background? But in reality, is accounting free of value, is it neutral? Of course, if we reflect on this matter again, we will find discrepancies. Namely, the accounting value may not be free, because the manufacturing process involves human individuals who have different personalities, and loaded will interest (Triyuwono, 2006).

Cnventional accounting does not have many mistakes, but there is a need for criticism of the concept. The use of critical-rational analytic methods. The use of criticalrational analytic methods. This method is applied keeping in mind the stages this is an attempt to compare concepts Western Accounting with the concept of Accounting Sharia. As is the case in the study effort or building social theories, including theories accounting, the analytical thinking process: critical and rational are highly demanded. In accounting research, critical approach (critical studies) is one approach which is recommended to be applied. Therefore, Cooper dan Hopper state that: "... critical accounting is critical of conventional accounting theory and practice and, through critical social science theory, it seeks to explain how the current state of accounting has come about" In a broader explanation, according to Lodh it is suggested, that: "... an accounting researcher can ask: what, how and why accounting rationale has become purposive, is being used, is to be used, and what are the means for doing so in a particular context?

Islamic accounting is present to deconstruct accounting with modern ideologies (Triyuwono, 2006). Through epistemology in pairs, Islamic Accounting seeks to contribute to 
accounting as an instrument in business activities, as well as as a medium in discovering the nature of human life goals. With humans being able to know the nature of their purpose in life, then, of course, all expectations, rules and certainly be a law-abiding person. Because his attitude is better or above all the rules. In another sense, people who are already religious are certain to obey laws and other rules made by humans and can follow developments in information technology. (Arwani, 2016).

According to Jenssen (1992), Social Problems are the difference between expectations and reality or as a gap between the existing situation and the situation that should be (Suharto, E., 1997). Social problems are seen by some people in society as an unexpected condition (Suharto, E., 2011). While according to Formm (1994), it is different that social problems if people want to function efficiently, then their members must have the traits that make them want to do what they are supposed to do as members of the community (Sugihen, B. T., 2015). The characteristics of social problems include conditions that are felt by many people, conditions that are considered unpleasant, conditions that require division and resolution of the problem must be resolved through collective action. Thus the theory of social problems the authors assume can be a knife of analysis in understanding the challenges and expectations of Islamic accounting facing the industrial revolution 4.0 .

To obtain the results of researchers using social problem theory. Because the prospects and challenges of Islamic accountants in the era of the industrial revolution 4.0 are part of social problems that require a solution to solve.

\section{LITERATURE REVIEW}

\section{Industrial Revolution Concept}

What exactly is the industrial revolution 4.0? Prof. Klaus Martin Schwab, German technician, and economist, who is also the founder and Executive Chairman of the World Economic Forum, introduced it. In his book The Fourth Industrial Revolution (2017), he mentioned that we are at the beginning of a revolution that fundamentally changes the way of life, work and relates to one another. The change is very dramatic and occurs at an exponential speed. (Ghufron, 2018)

This is indeed a drastic change compared to the previous industrial revolution era. In the Industrial Revolution 1.0, the growth of steam and water-based mechanization and energy became a marker. Human and animal power is replaced by the appearance of machines. Steam engine in the 18th century was one of the highest achievements. This 1.0 


\section{JURNAL AKUNTANSI INDONESIA}

revolution can increase the economy extraordinary. During the two centuries after the industrial revolution, the per capita income of countries in the world increased sixfold. (Prasetyo, B., \& Trisyanti, U., 2018)

The word "industry 4.0" surfaced in 2011 at the Hannover Fair and in 2013 at the same event a working group was formed, led by Siegfried Dais (Robert Bosch $\mathrm{GmbH}$ ) and Henning Kagermann (German Academy of Sciences and Engineering). The design principles used will be divided into 4 things, namely (1) Interconnection. Interpreted as the ability of machines, tools, sensors, and humans as users are connected using the Internet of Things (IOT) or the Internet of People (IoP); (2) Information transparency. Clarity of information obtained is used as well as a decision-making tool; (3) Technical Assistance (Technical Assistance). Divided into 2, namely the ability to visualize problems that occur and the ability to carry out tasks in areas dangerous to humans or workers. (4) Decentralized Decisions. The ability of the system to make their own decisions and complete tasks simultaneously or continuously. ( Iswanto, AC, \& Wahjono, W., 2019)

The era of the industrial revolution 4 gave birth to massive desperation which resulted in intense competition in various fields, politics, economics, accounting, education, social, and religious dogma. The six things that drive the emergence of desists are technology, the millennial generation, microprocessor speed, disruptive leader, changes in how to win, and the internet of things. Renald Kasali explained that the millennial generation's movement in responding to the industrial revolution 4 was like a snowball that continued to smuggle, increasingly larger and without limits. ( Setiawan, W., Suud, FM, Chaer, MT, \& Rahmatullah, AS, 2018)

Industrial Revolution 4 offers a variety of conveniences that are cheap, fast, and without limits. Human existence in maintaining socioeconomic routines began to face massive global changes. Accelerating changes in internet technology, artificial intelligence, and big data encourage each party to be able to compete in achieving a better life. The government continues to strive to achieve global targets in technology, social, political, and economic and accounting. ( Agung, AL, 2013)

Francis Fukuyama in his book, The Great Disruption: Human Nature and the Reconstitution of Social Order, explains that the transformation of society from an agricultural society into an industrial society and an industrial society has brought a broad influence of social change in human history, which he called the great disruption. ( Fukuyama, F., 2017). This can be explained through its causes, such as poverty and inequality, 
increasing wealth which led to the first conditions, the emergence of a modern welfare state, and extensive cultural shifts including the collapse of religion.

Modern capitalist society, according to Fukuyama, tends to destroy the power of social capital in society. Developed countries or industries have ignited the power of social capital without having the ability to rebuild it. ( Setiawan, W., Suud, FM, Chaer, MT, \& Rahmatullah, AS, 2018)

According to Popkoya et al in the book titled Industry 4.0: Industrial Revolution of the 21st Century, Studies in Systems, Decision and Control explains industry 4.0 is the next phase of the Knowledge Economy 3.0 based on Knowledge Economy, creative human resources play a key role as accelerators in the process the development and dissemination of Industry 4.0, Industry 4.0 is a new vector in the growth of the knowledge economy. To increase the number of personnel involved in this unique production system, the initiation of an educational environment is needed. The formation of Industry 4.0 will ensure the innovative development of a modern socio-economic system. The successful implementation of this approach is determined by the readiness of the countries of the world in conducting mutual cooperation and willingness to share their profits for the achievement of global economic prosperity along with maximum benefits for individuals in the future (Popkoya et all, 2019).

\section{Industrial Revolution 4.0 And Disruption}

In History, globalization shows that any change in the future has a core (driver) respectively. Friedman, Ritzer, and Toffler's description shows that the movement of change is always triggered by technological developments that gave birth to the era of the industrial revolution 4.0, which not only does not only open wide interactions but also disrupts various fields of human life. (Mustaqim, M., \& Bahruddin, A., 2015).

Disruptive was originally a phenomenon that occurred in the economic world, especially in the business sector. Clayton (Christensen, 1997), a Harvard Business Professor called it an innovative distribution in The Innovator 's Dilemma (Christensen, 1997). Disruptive itself is a condition when a business is required to continue to innovate to keep abreast of developments so that the business is not only to meet current needs but can anticipate future needs. (Prasetyo, B., \& Trisyanti, U., 2018)

In the era now, disruption does not only apply to the business world. The disruption phenomenon has a profound effect of change in various fields. Disruption does not only change the business but the fundamentals of the business (Khasali, 2018). Starting from the cost structure to the culture, and even the ideology of an industry. 
The business paradigm also shifted from the emphasis of owning to sharing (collaboration). Prasetyo, B., 2018). The phenomenon of disruption is not only happening in the business world. But it has expanded into other fields such as education, government, culture, politics, and law. In the political field, for example, political movements to gather them through mass concentration have been replaced by social media-based movements. The government sector is now also challenged to carry out bureaucracy effectively, efficiently based one governance. (Hopkin, A., 2002).

The cultural sector was also disrupted. The development of massive social media has reconstructed the cultural structure of society. Social relations of community relations are now more closely developed in cyberspace so that relationships in the real world become relative. Finally, the legal sector is now also disrupted. Legal regulations must also follow the development of existing technology, as when the ministry of transportation had difficulty applying rules to provide rules for online transportation. In short, disruptive regulation will occur disruptive regulation, disruptive culture, disruptive mindset, and disruptive marketing. (Khasali, 2018).

\section{The Role Of Humaniora Social Science}

Disruption has changed the world order rapidly. This change no longer takes thousands of years, as explained by Charles Darwin's theory of evolution (Darwin, 2004) in On the Origin of Species. Changes that only require a very short time. In that fast-paced situation, what changes is not only the phenomenon, for example, offline to online, the real world becomes a virtual world, print media becomes social media, and so forth. However, values, social order, and culture also experience changes. (Deacon, B., 2000).

The shift in values is reflected in the rise of various events that have recently taken place. The most pronounced impact is occurring in the environmental and social fields. Data from the Ministry of Environment and Forestry (KLHK) between July 2016-June 2017 shows deforestation of 497,000 hectares or $64.3 \%$ of the total forests in Indonesia. Although KLHK claims a decline from 2014 of 73.6\%, this number is still quite large, even though America, which is an industrial country, can maintain deforestation of no more than 200,000 hectares per year. Environmental problems also do not stop there, Indonesia and even categorized as the fourth dirtiest country in the world, according to the 2015 International Earth Science Information Network.. (Mangunjaya, FM, 2008)

Damage to nature is simply not just caused by waste from the production process. Behind that, there was a shift in the human paradigm in looking at nature (Prasetyo, 2018). In 
this case, Max Weber states that since modernity has proliferated, humans have only used " instrumental reason ", which then treats nature as something that can be manipulated, with results that can be directed (Tempo, 2010). As a result, the modern world and ecological damage are fast interlockings. Humans while separated from nature, and live in another reality. This alienation makes man's relationship with nature only subject and object: human (subject) who controls nature (object). (Prasetyo, B., \& Trisyanti, U., 2018)

In addition to having an impact on environmental issues, the industrial revolution will also leave issues related to the loss of social values in the humanities. The millennial generation, the generation born around 1980-2000s, have shown symptoms of mental degradation. The consumerism lifestyle, unlimited freedom, and the loss of ethical behavior on social media are a series of examples of this degradation. Rhenald Kasali (Khasali, 2018) refers to millennial as the strawberry generation, which is described as an attractive generation, but fragile because it does not have a strong mentality and values.

The initial spirit of technological advancements is to facilitate human life. Since the invention of the machine and the start of the automation era, production has doubled and cut time and costs. However, in the end, all these conveniences have a big impact on humans, because it makes the use of human labor significantly reduced. As a result, an increase in the number of unemployed. Right at this point, it is necessary to have a development paradigm that not only enhances human capability in technology but also needs to improve the mentality of its people.

In the effort to build the character, the role of social science in humanities is needed. It is unfortunate, on several occasions, humanities are considered second class sciences which lack a significant impact in the era of the industrial revolution 4.0. If explored further, the development of science (science) that produces technological advances today starts from the rationality that is trained by humanities. The movement was reflected when the birth of modern times in the century around XVII (Hardiman, 2004). In that era, the era of awakening ratios had begun, allowing humans to think free of the theological doctrines that were bound.

In the XVIII century, there was a big change in the way of human thinking. This is marked by the secularization of knowledge so that the separation between body and soul is studied separately. Parts of the body are treated as material and are explained as is the case with natural phenomena. Natural science is separate from social science and humanities. Towards the end of the twentieth century, advances in science and technology accelerated so that life and livelihood technology was created (Jacob, 1988) 


\section{JURNAL AKUNTANSI INDONESIA}

Technology develops itself and becomes increasingly separate, and is far from religion and ethics, law, social science, and humanities. Therefore, there must be an effort to equate technology education with humanities. Knowledge about nature and life is not complete without the knowledge of why something happened, how it happened, how the next development and how it should and should. Hard technology is not complete without soft technology (Jacob, 1988)

\section{METHOD}

This research uses descriptive of literature study. Descriptive of literature study is research that is more specific to the understanding of social problems based on real conditions that are complex and detailed. (Indriantoro and Supomo, 1999). In research trying to read several books, journals and references related to the topics discussed. The literature method is one of the data collection methods used in social research methodologies to trace historical data (Bungin, 2008). Descriptive method is a method that focuses on examining a group of people, an object, a condition, a thought, or an event in the present that aims to describe or describe accurately, factually, and systematically about facts, traits and relationships between phenomena. researched. Literature study means data collection techniques by making a study of books, literature, notes, and reports relating to the problem under study (Zed, 2008). Social problems are conditions that many people find unpleasant, disrupting the social functioning of a number of people, and their reasons for asking for collective solutions. One of the social problems is the challenges and hopes of Islamic accountants in the Industrial Revolution 4.0 era. By using social problem theory is expected to make a positive contribution in solving the overall problem. The theory of Jensen's and Formm's social problems discussed in his book Edi Suharto (Suharto, 2011) can be used to analyze the challenges and expectations of Islamic accounting in the face of the industrial revolution 4.0.

\section{RESULT AND DISCUSSION}

\section{Accounting And Changes}

Changes in the business environment and accounting profession. the dynamics that take place in the supra system of technological environments and politic, economic, and social that interact with each other in a very complex fabric are transforming the industrial society into an information society or knowledge society. Changes in the supersystem will certainly have a very big impact on the internal business environment so that lately has increasingly promoted the transformation process in organizations and management, from 
corporate governance to a "hierarchical, mechanistic, autocratic and confrontational" structure to a "networked, organic, participatory and coexistence" structure. ". (Prakarsa, W., 1996)

Changes which involves vision, mission, and strategy, as well as the further adaptation in culture, structure, and system that goes well in the development of micro and macro organization's environmental impact, was very big on the accounting carrying accountability and decision support functions in ipoleksos environment. (Inanna, I., \& Rahmatullah, R., 2018). In an environment where the change is not changing, the transformation that occurs in the internal environment of the accounting profession such as the expansion of technical standards both domestically and internationally, the expansion of the range of services offered, improvement of educational requirements, tightening of quality control, improvement of work responsibilities, and academic support are contemporary challenges faced by the accounting profession are likely to continue in the future. In his paper entitled "Infoteracy", Drucker stated that companies generally have two information systems. The first system organized around external data flows and other systems that are much older and organized around internal data flows is the accounting system. despite being 500 years old, the appearance of the accounting system today is still very chaotic. (Indrajit, RE, 2000).

Changes in technology information 20 years will come, according to Drucker, is not anything compared to the changes that would occur in accounting. Furthermore, it was also stated that improvements were taking place in manufacturing cost accounting which had been in the status quo position since the 1920s and today has been using (Hesselbein, F., \& Goldsmith, M., 2013). While service business accounting still faces an unsolved problem due to the difficulty in linking expenditure with the results achieved. Finally, although today still separate from one another, the system organized around external and internal data, according to Drucker's projections, will merge in the future so that top management does not only depend on financial accounting information systems that have been easily manipulated and only explain what has happened - not what will happen - but also in the information system in a broader sense.

Accounting and other information practices that develop in the business world are accountability and decision support systems that can influence the expectations and behavior of stakeholders in the decision-making process and actions intended to transform physical systems so that they have greater capability to face the increasingly fierce arena of competition in future. Furthermore, research in tertiary institutions, among others, is carried 


\section{JURNAL AKUNTANSI INDONESIA}

out by comparing what happens in the real world (physical systems) with models used in accounting practices (conceptual systems) to find skills, expertise, knowledge or contemporary professional orientation that is more conducive in the process of forming good governance. (Emirzon, J., 2006).

The problems have arisen as a result of some of the fundamental problems in corporate governance that include the supply and demand of accounting information which is incomplete and the high cost of monitoring to close the opportunity to present the financial statements more perfect. (Lilis Sulastri, NPM, 2013). These problems are clearly the challenges that accounting education must face in general and accounting research in accounting in particular because in order to improve corporate governance accounting experts must find solutions from three groups and in terms of regulation: (1) a better financial reporting system; (2) increasing the reader's knowledge in order to better understand financial statements; and (3) provide input to regulators in order to formulate regulations that can reduce market distortions caused by information asymmetry. (Anwar, $A$. A, 2013).

Various weaknesses that confirm that the accounting system in the development of less adaptive to changes in the business environment. It must be recognized that the state of the art accounting system that is known so far is the business infrastructure in the era of the industrial revolution that is mechanistic. The system is no longer compatible with the infrastructure of the business environment in the era of information and communication revolution which tends to be more organic. In the contemporary environment, in addition to improving financial reporting in accounting, integration between internal and external information systems that Drucker projected in advance seems inevitable because of the tendency to: (1) simplify processes or exclude various activities that do not create added value; (2) fostering collaboration of various cross-functional activities along the internal and external value chains that even cross national borders (co-operation); and (3) internalize information and communication technology into mechanistic systems that were previously implemented manually - demanding uniformity and compatibility of information systems.

\section{Challenges and Expectations of Islamic Accounting}

Furthermore, Islamic accounting produces a formulation related to the basic objectives of financial statements (Triyuwono, 2006), namely: first to provide information, both financial and non-financial. Financial information, in this case, is information generated from financial transactions, while non-financial information is information that 
cannot be quantified or is not related to finance. It can be in the form of mental assets such as the morality of employees, also spiritual assets, namely the level of devotion from the management and all existing employees. Surely these two things have not been touched in the report presented by modern accounting.

The second basic objective of Islamic Accounting financial statements is related to accountability. In this case, accountability in question is horizontal and vertical. Where the horizontal is a form of accountability to fellow humans, namely internal company or external parties. Whereas vertical accountability is how the financial statements can also be accounted for before God. Of course, this can reduce various interests, even potential fraud. Accounting information like this which is certainly very much needed by any entity. So expect will increasingly relevant studies Islamic Accounting, followed by the number application of the existing as well as subsystems and systems Islamic accounting.

As one of the subsystems in the Islamic Accounting system in particular and the Islamic Accounting informs system, in general, will be more dominant in the future due to its function to produce knowledge workers who can provide support for other knowledge workers in the process of creating added value. If the profession of accounting that is therein accountant sharia can take advantage of the opportunities that open wide, according to Elliott, no one administrator universities who will treat accounting as a discipline with relevance marginal as in the past. The role of accounting and Islamic accounting will be increasingly vital in the period ahead - vital to understanding what that was going on in the economy; vital to harmonize conflicts of interest in between the stakeholders; vital for production, consumption, savings and investment decisions; vital in the management of both business in general and aspects of business in an organization nonprofit, $t$ include university 's own; and as has been alluded to in advance, vital for good corporate governance. Vitality system information accounting that seems to be redundant without followed by revitalizes system of accounting. (Nurdiantini, D, 2016). Will but on the contrary in the positive, the era of digitalization potentially increase the power of work just as much as 2.1 million up to the year 2025 means that there is a large selection of professions and jobs are varied. Besides, automation and digitization can reduce the potential for carbon emissions by 26 billion metric tons ( World Economic Forum, 2016 and Gap, G. G, 2017) ).

Explains concerning the characteristics and the focus of the industry 4.0 it is already clear the position of the profession of accountants and therein accountant sharia which must follow the rhythm and the rhythm faster than the revolution it. Rather - rather eroded or able to defend against changes that, so that accountants will face in positions: (1) Signal admit to 


\section{JURNAL AKUNTANSI INDONESIA}

noise. Accountants are already aware of the threat and will be ready to take advantage of the momentum of the opportunities from threats such to be able to take the benefits ; (2) Changes takes hold. Accountants and Islamic accountants already feel a change in their activities but feel no need to take a stand because they have not disturbed the "status quo". (3) The inevitable transformation. Accountant already do change due to the performance of "status quo" has been disrupted by the revolution 's and accountants should do the transformation changes with rapid and methods best just for a couple of aspects that are deemed necessary. Adapting to the new normal. The transformation of the accounting profession as a whole according to the demands of the new industry 4.0 model or the accounting profession will be lost if it is unable to adapt to these changes. (Iswanto, AC, \& Wahjono, W., 2019). From the explanation of the position of accountant above, it would appear the challenge and influence of the profession of accountants and accountants sharia among others where the development of technology to change business as significantly as many assets are in the form of " technology " and not tangible in the physical, not much need a source of power humans included therein staff accounting, companies do not have the concept of " place " or "premises" because it is controlled through the "virtual office" and the latter on how to market and how to sell through "market place" or "online store" that all of them had to be heading to a point of balance or equilibrium new which later formed their standards (Noviari, N., 2009).

In the past 5 years in the future where technology $5 G$ in devices of telecommunications has been adopted in full (Hidayat, R., \& Herdin , E. L, 2018), access to the internet in speed Gigabit per second and the device hardware are also humans already connected to one each other both in IOT or IOP, will change the role of accountants and accountants sharia are replaced by technology Al (Artificial Intelligence) and robotics to do the work of basic accounting are recorded transactions, processing transactions, sort out the transactions, do automation of making statements finance simultaneously analyze reports finances are in independently without interfering hand of man. (Iswanto, AC, \& Wahjono, W., 2019)

The pattern of self-management functions of basic accounting and accountants sharia here that would increase the efficiency and effectiveness of the work and the results are known when it also (real-time). Many companies are already developing the case is because already supported the standardization process of managing financial and standardized architecture system information that is adequate and appropriate demands of industrial generation of four so that competence is crucial that required for the accountant 
further is the ability of the analysis of the data, follow the development of technology information and update the style of leadership . (Aminah, USA, 2015).

Farther more impact is the accountant and Islamic accountant, as well as office accountant, will be "forced " to develop applications move (mobile) to be able to access the data indirectly from the device phone handheld, tablet and virtual reality (VR). Audit reports finances do base on real-time where regulators and auditors interesting data that is needed is automatically directly from the system and sensors attached to the activities of operational so that the transparency and accuracy of the data that is generated can be accounted for justified. If the accountant does not have the expertise that is adequate in the technology of information the profession else can take over the functions of accountants, so it can be said to be the technology of information is the need principal that must be met to be learned and understood by the accountant 's own (Alhamdaniah, I., 2017). So from that expected all people to be part of the change that. It is also the pressure for an institution of education to create a curriculum that is relevant for students of accounting to adjust with connectivity digital so it is expected the graduates who will be the accountant can adapt to the digital age when it.

Changes era indeed not be avoided, then of it should always be able to control the reaction and attitude towards the change of the order could come forward to follow the development of the times. In the sector of accounting, various challenges that are present as the coming of the digital age not be left so alone should be studied with the well to determine the attitude to overcome it. Fluent in technology is one of the keys to facing challenges in this era.

\section{CONCLUSION AND RECOMMENDATION}

The era of the industrial revolution 4 which offers comfort and speed makes people turn super fast. Technology is used and developed to accelerate the achievement of every goal set by humans. Eventually, material and psychological needs become unavoidable to be forgotten, it will only increase. Professional accountants and sharia accountants need a pattern of self-management of the basic functions of Islamic accountants and accountants which certainly increases work efficiency and effectiveness and the results are immediately known (real-time). The findings of this study include the challenges of Islamic accounting in the face of the industrial revolution including the provision of information that is financial and non-financial IT-based, accountability of financial statements in accordance with SAK Sharia is the main basis for policy makers, Sharia accountants must understand the 


\section{JURNAL AKUNTANSI INDONESIA}

development of IT-based economics and be able to harmonize conflicts of interest by following the development of information technology. The expectation of Islamic accountants in facing the industrial revolution can be accepted and has the knowledge and skills of IT-based SAK Sharia and can apply digital-based technology, Islamic Accountants always want to innovate in technology development and Islamic accountants are always adaptive in economic and technological development and always want to learn throughout time. Recommendations for policy makers to pay attention to sharia accountants to give an agreement to contribute in the economic and financial fields and IAI professional institutions to update IT-based SAK Syariah so that sharia accountants can always be adaptive, creative and innovative.

\section{REFERENCES}

Agung, A. L. (2013). Human Capital Competencies. Elex Media Komputindo.

Anwar, A. A. (2013). Analisis Perspektif Stakeholder Terhadap Implementasi Corporate Social Responsibility (CSR).

Arwani, A. (2016). Akuntansi Perbankan Syariah: dari Teori ke Praktik (Adopsi IFRS). Deepublish.

Arwani, A. (2017). The Future of The Profession of Accountant Sharia Enter MEA In 2017. International Journal of Islamic Business and Economics (IJIBEC), 31-41.

Burange, A. W., \& Misalkar, H. D. (2015, March). Review of Internet of Things in development of smart cities with data management \& privacy. In 2015 International Conference on Advances in Computer Engineering and Applications (pp. 189-195). IEEE.

Cooper, W. J., Cooper Jr, W. J., \& Terrill, T. E. (2009). The American south: A history (Vol. 2). Rowman \& Littlefield.

Darwin, C. (2004). On The Origin Of Species. castle book.

Deacon, B. (2000). Globalization and social policy: The threat to equitable welfare (No. 5). Geneva 2000 Occasional Paper.

Emirzon, J. (2006). Regulatory Driven Dalam Implementasi Prinsip-Prinsip Good Corporate Governance Pada Perusahaan di Indonesia. Jurnal Manajemen \& Bisnis Sriwijaya, 4(8), 93-114.

Fukuyama, F. (2017). The great disruption. Profile Books.

Gap, G. G. (2017). World economic forum. Cologny/Geneva. 
Ghufron, G. (2018, September). Revolusi Industri 4.0: Tantangan, Peluang, Dan Solusi Bagi Dunia Pendidikan. In Seminar Nasional dan Diskusi Panel Multidisiplin Hasil Penelitian dan Pengabdian Kepada Masyarakat 2018 (Vol. 1, No. 1).

Hardiman, F. . (2004). Filsafat Modern: Dari Machiavelli Sampai Nietzsche. jakarta: gramedia pustaka utama.

Harto, K. (2018). Tantangan Dosen PTKI di Era Industri 4.0. Jurnal Tatsqif, 16(1), 1-15.

Hesselbein, F., \& Goldsmith, M. (2013). The leader of the future 2. Elex Media Komputindo.

Hopkin, A. . (2002). Globalization In World History. Iondon: pimlico

Inanna, I., \& Rahmatullah, R. (2018). Wajah Perekonomian Indonesia.

Indrajit, R. E. (2000). Manajemen Sistem Informasi dan Teknologi Informasi. Jakarta: PT Elex Media Komputindo.

Indriantoro, Soepomo \& Bambang Supomo. (1999). Metodologi Penelitian Bisnis. Edisi 1.

Yogyakarta. BPFE.

Iswanto, A. C., \& Wahjono, W. (2019). PENGARUH REVOLUSI INDUSTRI 4.0 TERHADAP ILMU AKUNTANSI-ESAI. INFOKAM, 15(1).

Jacob, T. (1988). Manusia IImu dan Teknologi. yogyakarta: Tiara wacana.

Keoh, S. L., Kumar, S. S., \& Tschofenig, H. (2014). Securing the internet of things: A standardization perspective. IEEE Internet of things Journal, 1(3), 265-275

Khasali, R. (2018). Strawberry Generation. Jakarta: Mizan.

Lilis Sulastri, N. P. M. (2013). Kajian Manajemen Berbasis Nilai Dalam Konteks Perguruan Tinggi (Studi Kasus pada Perguruan Tinggi Binus University) (Doctoral dissertation, UNPAS).

Mangunjaya, F. M. (2008). Bertahan di bumi: gaya hidup menghadapi perubahan iklim. Yayasan Pustaka Obor Indonesia.

Mustaqim, M., \& Bahruddin, A. (2015). Spirit Gusjigang Kudus dan Tantangan Globalisasi Ekonomi. Jurnal Penelitian, 9(1).

Noviari, N. (2009). Pengaruh Kemajuan Teknologi Informasi Terhadap Perkembangan Akuntansi. Jurnal Ilmiah Akuntansi dan Bisnis.

Nurdiantini, D. (2016). Pengaruh Partisipasi Pengguna Terhadap Kualitas Sistem Informasi Akuntansi Survey Pada 3 Perusahaan Maskapai Penerbangan (Sriwijaya Air, Lion Air, dan Kalstar Aviation) di Bandung (Doctoral dissertation, Fakultas Ekonomi Unpas).

Popkova, Elena G.; Ragulina, Yulia V.; Bogoviz, Aleksei V, (2019), Industry 4.0: Industrial Revolution of the 21st Century, Studies in Systems, Decision and Control, Volume 169, Springer International Publishing AG, Switzerland. 


\section{JURNAL AKUNTANSI INDONESIA}

Prakarsa, W. (1996). Transformasi pendidikan akuntansi menuju globalisasi. Konvensi Nasional Akuntansi III. Jakarta: Ikatan Akuntansi Indonesia.

Prasetyo, B. (2018). Alam dan Manusia. Waskita, 37-46.

Prasetyo, B., \& Trisyanti, U. (2018). Revolusi Industri 4.0 dan Tantangan Perubahan Sosial. IPTEK Journal of Proceedings Series, (5), 22-27.

Purwandini, D. A., \& irwansyah, i. Komunikasi korporasi pada era industri 4.0. Jurnal I/mu Sosial, 17(1), 53-63.

Roblek, V., Meško, M., \& Krapež, A. (2016). A complex view of industry 4.0. Sage Open, 6(2), 2158244016653987.

Setiawan, W., Suud, F. M., Chaer, M. T., \& Rahmatullah, A. S. (2018). Pendidikan Kebahagiaan dalam Revolusi Industri 4. AL-MURABBI: Jurnal Studi Kependidikan dan Keislaman, 5(1), 101-120.

Sugihen, B. T. (2015). Pengendalian Masalah Sosial Melalui Kearifan Lokal. Syiah Kuala University Press.

Suharto, Edi. (1997). Pembangunan, Kebijakan Sosial,\& Pekerja Sosial. Bandung: LSP STKS

Suharto, Edi. (2011). Kebijakan sosial. Bandung: Alfabeta

Triyuwono, I. (2006). Perspektif, Metodologi, dan Teori Akuntansi Syariah. PT RajaGrafindo Persada.

Website: https://fecon.uii.ac.id/blog/2018/12/09/tantangan-implementasi-keuangan/_akses: 20-1-2020.

Zed, Mestika. (2008). Metode Penelitian Kepustakaan. Edisi 2. Jakarta. Yayasan Obor Indonesia. 